\title{
A COMPANHIA DAS ÍNDIAS OCIDENTAIS: UMA SOCIEDADE ANÔNIMA?
}

THE DUTCH WEST INDIA COMPANY: A STOCK CORPORATION?

Roberto Chacon de Albuquerque*

\begin{abstract}
Resumo:
Neste artigo, o Autor analisa a natureza jurídica da Companhia das Índias Ocidentais. Uma sociedade com uma estrutura híbrida, de direito público e de direito privado, a Companhia deteve no século XVII o monopólio da navegação e do comércio com as Américas e a África Ocidental, tendo conquistado temporariamente parte do Brasil. A Companhia das Índias Ocidentais não deve ser considerada uma antecessora das sociedades anônimas, mas a precursora de uma relação simbiótica entre o público e o privado.
\end{abstract}

Palavras-chave: Companhia das Índias Ocidentais. Sociedade anônima. Monopólio.

\begin{abstract}
:
In this article, the author analyzes the legal nature of the Dutch West India Company. A company with a hybrid structure, of public and private law, it obtained during the $17^{\text {th }}$ century the navigation and trade monopoly with the Americas and Western Africa, having temporarily conquered a part of Brazil. The Dutch West India Company should not be considered as an ancestor of stock corporations, but as the predecessor of a symbiotic relation between public and private interests.
\end{abstract}

Keywords: Dutch West India Company. Stock corporation. Monopoly.

Introdução

A Companhia das Índias Ocidentais, que teve como maior realização em toda sua história a conquista temporária de parte do Brasil de 1630 a 1654, o Brasil holandês, que passou a ser conhecido como a Nova Holanda, ${ }^{1}$ não foi criada com um objetivo exclusivamente comercial. Ela foi um instrumento da política exterior holandesa para conquistar colônias portuguesas e espanholas nas Américas e na África Ocidental. Para além do continente europeu, no século XVII, portugueses e espanhóis continuavam tentando assegurar o controle da navegação e do comércio no Atlântico. Os ibéricos haviam descoberto, no século XV, o Novo Mundo. Com o Tratado de Tordesilhas, de 1494, Portugal e Espanha, com aprovação papal, haviam dividido o mundo entre si. Os ibéricos sentiam-se legitimados religiosa e politicamente para exercer o monopólio da navegação e do comércio da Europa com as Américas e a África Ocidental. Durante o século XVI, portugueses e espanhóis foram os senhores do Atlântico. Eles praticamente não tiveram

Advogado, Doutor em Direito pela Universidade de São Paulo, Professor da Universidade Católica de Brasília.

1 O Brasil holandês foi denominado oficialmente pelos Países Baixos como sendo a Nieuw-Holland. 
rivais, conseguindo colocar em prática sua estratégia expansionista. A hegemonia ibérica começou a ser ameaçada seriamente apenas a partir do século XVII. Aventureiros, comerciantes, navegadores e piratas franceses, holandeses e ingleses passaram a visitar, saquear e invadir as colônias portuguesas e espanholas. O monopólio ibérico da navegação e do comércio da Europa com as Américas e a África Ocidental revelou-se cada vez mais insustentável, um verdadeiro anacronismo. O Brasil não escapou deste cenário de conflito entre as potências européias. Ele se tornou um dos principais objetos de cobiça para a política exterior holandesa, cada vez mais interessada em suas riquezas. ${ }^{2}$

Para tentar conquistar colônias portuguesas e espanholas nas Américas e na África Ocidental, os holandeses inspiraram-se no modelo bem-sucedido da Companhia das Índias Orientais, fundada em 1602. Dotada do monopólio da navegação e do comércio com a Ásia, esta Companhia pode ser considerada a primeira multinacional do mundo e a primeira sociedade a emitir ações. Da mesma maneira que os Países Baixos queriam excluir com a Companhia das Índias Orientais os outros países europeus do comércio com a Ásia, eles pretendiam com a Companhia das Índias Ocidentais afastar os outros países europeus do comércio com as Américas e a África Ocidental. Durante a Trégua dos Doze Anos dos Países Baixos com a Espanha, de 1609 a 1621, os Estados Gerais, o Governo Central dos Países Baixos, não autorizaram a fundação da Companhia das Índias Ocidentais, com o receio de que Madri interpretasse esta fundação como uma declaração tácita de guerra, uma violação da Trégua dos Doze Anos. ${ }^{3}$

Para levar adiante seu projeto expansionista nas Américas e na África Ocidental, com a fundação da Companhia das Índias Ocidentais, os Países Baixos, pretendendo evitar uma confrontação direta com a Espanha, decidiram aguardar. Somente a partir de 1621, com o término da Trégua dos Doze Anos, este confronto de interesses foi superado. Não havia mais obstáculos políticos, sob o ponto de vista do direito internacional, para a fundação da Companhia das Índias Ocidentais.

1. Navegação, guerra e comércio

Os Países Baixos viviam um delicado equilíbrio de forças com a Espanha. Contrabandistas holandeses violavam amiúde o monopólio ibérico da navegação e do comércio da Europa com as Américas e a África Ocidental. Tolerado pela Espanha em virtude da escassez de meios para deter estas violações, o contrabando passou a ser severamente combatido somente a partir da ascensão, em 1556, de Filipe II ao trono

HEIJER, Henk den. De geschiedenis van de WIC. Walburg Pers: Zutphen, 2002. p. 13: "Ook Brazilië, dat grote hoeveelheden vefhout leverde, werd steeds frequenter bezocht".

3 Com a separação dos Países Baixos da Espanha, os Estados Gerais, o Parlamento dos Países Baixos, tornaram-se a autoridade central e soberana. 
espanhol. Os contrabandistas holandeses contavam com a conivência do Governo holandês. Diante das dificuldades que eles passaram a enfrentar com Filipe II, os Países Baixos não tardaram a defender o que eles consideravam ser seus interesses nacionais. Não demorou para que o contrabando suscitasse conflitos armados entre os Países Baixos e a Espanha. Para os holandeses, Filipe II queria apenas defender o anacrônico monopólio ibérico da navegação e do comércio da Europa com as Américas e a África Ocidental. ${ }^{4}$ Algumas das principais regiões dos Países Baixos, como a Holanda, a Zelândia e a Frísia Ocidental, haviam-se destacado desde o século XVI com grandes navegadores e comerciantes na Europa, ocupando um lugar cada vez preponderante. Os Países Baixos sentiam-se como se fossem os grandes ausentes da navegação e do comércio da Europa com as Américas e a África Ocidental. Não podiam admitir a hegemonia ibérica.

Dos produtos que foram trazidos pelos Países Baixos à Europa, estima-se que o açúcar tenha sido o primeiro. Para chegar às cidades holandesas, o açúcar costumava passar tradicionalmente por Lisboa. Este não era o caminho preferido pelos Países Baixos. Para não se submeterem a controles alfandegários, políticos e tributários, os holandeses preferiam privilegiar uma conexão direta dos Países Baixos com as principais regiões produtoras de açúcar, como a Ilha da Madeira, a Ilha de São Tomé, as Ilhas Canárias e o Brasil. Navios holandeses partiam diretamente de Amsterdã, Roterdã e Midelburgo, as principais cidades mercantis holandesas, para estas regiões. Desde o século XVI, os Países Baixos tinham suas próprias refinarias de açúcar. Em 1594, Roterdã dispunha de três refinarias, enquanto Amsterdã naquele mesmo ano devia dispor de quatro refinarias. ${ }^{5}$ A partir de século XVII, a importância do açúcar para a economia holandesa tornou-se cada vez maior, contribuindo consideravelmente para a pujança dos Países Baixos. ${ }^{6} \mathrm{O}$ açúcar refinado era vendido e distribuído ao resto da Europa.

O estado de guerra permanente entre os Países Baixos e a Espanha terminou sendo temporariamente arrefecido apenas com a celebração da Trégua dos Doze Anos, em 1609. ${ }^{7}$ A navegação e o comércio dos Países Baixos com a Península Ibérica foram retomados, em especial os contatos com Portugal, mas as hostilidades não cessaram durante muito tempo. Com o final desta Trégua em 1621, a Espanha tentou novamente coibir a violação do seu monopólio da navegação e do comércio da Europa com as Américas e a

4 De 1580 a 1640, com o desaparecimento de D. Sebastião, rei português, Portugal e Espanha constituíram um só país, a União Ibérica, governada sucessivamente pelos três Filipes: Filipe II, Filipe III e Filipe IV.

$5 \quad$ HEIJER, Henk den. op. cit., p. 15: "In 1594 telde Rotterdam reeds drie raffinaderijen, terwijl Amsterdam er in dat jaar waarschijnlijk vier binnen haar muren huisvestte"

$6 \quad$ Id. Ibid., p. 15: "In de loop van de zeventiende eeuw zou de suikerraffinage uitgroeien tot een bloeiende bedrijfstak, die een belangrijke bijdrage zou leveren aan de welvaart van de Republiek"

7 Espanha e os Países Baixos, antes de celebrarem a Trégua dos Doze Anos, passaram por um longo e penoso período de hostilidades mútuas, que ainda se prolongou por décadas após a cessação desta Trégua. Para que os Países Baixos se tornassem independentes da Espanha, foi necessária uma guerra de secessão que durou oitenta anos, a Guerra dos Oitenta Anos, de 1568 a 1648. 
África Ocidental, sem muito sucesso. Comerciantes holandeses, com ou sem a autorização ibérica, continuaram a buscar sal na Região do Caribe. O sal era de importância vital para a conservação do pescado, em especial do arenque, então uma das principais fontes de alimentação dos países nórdicos. Mas as atenções dos Países Baixos logo não se concentrarem mais no sal. $\mathrm{O}$ açúcar havia-se transformado cada vez mais no principal objeto da cobiça dos comerciantes holandeses. Para Amsterdã, Roterdã e Midelburgo, o comércio de açúcar não podia ainda ser considerado uma atividade tradicional. $\mathrm{O}$ mesmo não podia ser afirmado para Antuérpia, principal cidade mercantil de Flandres, região ao sul dos Países Baixos. Com a ocupação espanhola desta cidade, muitos comerciantes haviam fugido para os Países Baixos, levando consigo todo o conhecimento que haviam acumulado no comércio do açúcar. $\mathrm{O}$ monopólio ibérico da navegação e do comércio da Europa com as Américas e a África Ocidental não podia mais ser sustentado. Os comerciantes holandeses ansiavam pelo açúcar do Brasil e pelo marfim, pimenta e ouro da Costa do Ouro. ${ }^{8}$

Embora combatessem com todas as forças de que dispunham o monopólio ibérico, os comerciantes holandeses não tinham como objetivo estabelecer a livre concorrência na navegação e no comércio da Europa com as Américas e a África Ocidental. Seu objetivo era outro. Eles pretendiam minar o monopólio ibérico, mas ao mesmo tempo combater a livre concorrência e os riscos que ela acarretaria. Desde o começo do século XVII, os comerciantes holandeses passaram a associar-se em diferentes companhias com o objetivo de estabelecer justamente o monopólio holandês da navegação e do comércio da Europa com as Américas e a África Ocidental. Estas companhias tiveram como objetivo controlar o comércio com as Américas e a África Ocidental até a fundação da Companhia das Índias Ocidentais. ${ }^{9}$ Divergências políticas e econômicas entre as duas regiões mais importantes dos Países Baixos, a Holanda e a Zelândia, não permitiram durante décadas que se fundasse uma única companhia consagrada à navegação e ao comércio da Europa com as Américas e a África Ocidental. Para que a Companhia das Índias Ocidentais fosse fundada, seria necessária a intervenção do Governo Central dos Países Baixos, uma federação, os Estados Gerais. Durante sua existência, as companhias funcionaram como uma série de corporações de comerciantes que apoiavam política e financeiramente os Estados Gerais, sobretudo quando os Países Baixos estavam em guerra, na medida de suas possibilidades e de seus interesses.

Os comerciantes holandeses haviam estabelecido companhias que pretendiam dominar o comércio com as regiões mais distantes e díspares que se possa

A Costa do Ouro equivale aproximadamente ao território que hoje é ocupado por Gana, na África Ocidental. HEIJER, Henk den. op. cit., p. 18: "Te zamen zouden zij de handel op West-Afrika beheersen tot aan de oprichting van de WIC" 
imaginar. Havia uma companhia de comércio, controlada por Balthasar de Moucheron, sediada em Midelburgo, Zelândia, com atividades que se estendiam desde Arkhangelsk, no Oceano Ártico, até o Brasil, no Oceano Atlântico. ${ }^{10} \mathrm{O}$ monopólio ibérico da navegação e do comércio da Europa com as Américas e a África Ocidental estava sendo substituído por uma rede de companhias de comércio holandesas com pretensões igualmente hegemônicas, dotada de ramificações cada vez mais disseminadas em regiões que antes eram controladas com exclusividade pelos portugueses e pelos espanhóis. O maior obstáculo ao expansionismo dos Países Baixos nas Américas e na África Ocidental continuava sendo os portugueses. ${ }^{\text {I }}$ Os comerciantes holandeses estavam ávidos por especiarias asiáticas. Para alcançar a Ásia, os Países Baixos precisavam de um entreposto seguro na África, a caminho da viagem para a Ásia, um ímã para os comerciantes holandeses. ${ }^{12}$ Uma região, situada dentro da esfera do monopólio ibérico de comércio e navegação com as Américas e a África Ocidental, que atraía o interesse dos comerciantes holandeses, era a América do Norte. No mesmo ano da celebração da Trégua dos Doze Anos com a Espanha, 1609, os Países Baixos, com o financiamento da Companhia das Índias Orientais, encarregaram Henry Hudson, explorador e navegador inglês, de encontrar um caminho alternativo para a Ásia, através da América do Norte. Ele não chegou ao destino pretendido, mas a uma ilha estreita e comprida conhecida atualmente como Manhattan. Johannes de Laet, primeiro historiador da Companhia das Índias Ocidentais, em sua obra Novo Mundo, terminaria descrevendo-a como "uma ilha tropical cheia de leite e mel" ${ }^{13}$ Não seria o "leite e mel" da Ilha de Manhattan que atrairia os comerciantes holandeses, mas as peles de que os europeus mais afortunados precisavam para aquecerem-se no inverno. Não tardou para que Lambert van Tweenhuysen, um dos principais comerciantes envolvidos no comércio de peles, tentasse obter para si mesmo uma fração do repudiado monopólio ibérico da navegação e do comércio da Europa com as Américas e a África Ocidental com a fundação de uma companhia que tinha como objeto a América do Norte, rejeitada pelos Estados Gerais. A situação deteriorou-se rapidamente. Três companhias terminaram surgindo com o mesmo objetivo, a obtenção do direito exclusivo da navegação e do comércio com a

10 HEIJER, Henk den. op. cit., p. 20: "Een man die de handel op West-Afrika bijzondere vermelding verdient, is Balthasar de Moucheron. Deze onderrnemende koopman stond aan het hoofd van een in Middelburg gevestigde handelsonderneming die haar activiteiten uitstrekte van Archangelsk an de Witte Zee tot Brazilië in de Zuidelijke Atlantische Oceaan"

1 Nas Américas, os portugueses controlavam o Brasil, na África, boa parte da África Ocidental.

12 Balthasar de Moucheron chegou a estabelecer para a viagem à Ásia a Veerse Compagnie (Cf. HEIJER, Henk den. De geschiedenis van de WIC. Walburg Pers: Zutphen, 2002, p. 20: “Azië trok als een magneet tal van ondernemende kooplieden uit de Republiek aan, onder wie Balthasar de Moucheron, die voor de vaart op dit werelddeel de Veerse Compagnie hielp oprichten").

13 HEIJER, Henk den. op. cit., p. 21: "De latere geschiedsschrijver van de WIC, Johannes de Laet, zou in een reisbeschrijving getiteld Nieuwe Wereldt zijn lezers voorhouden dat Hudson een tropisch land, overvloeiende van melk en honing, had ontdekt". 
América do Norte, batizada de Novos Países Baixos. ${ }^{14}$ Objeto de uma fusão, em 1614, elas deram origem com o aval dos Estados Gerais à Companhia dos Novos Países Baixos. Ela nasceu dotada de monopólio nas viagens aos Novos Países Baixos, tendo fundado várias feitorias ao longo do Rio Hudson, berço da cidade de Nova York. Esta fragmentação do monopólio ibérico da navegação e do comércio da Europa com as Américas e a África Ocidental entre várias companhias holandesas era insustentável política e financeiramente. Os Estados Gerais precisavam dispor de uma única companhia holandesa que controlasse toda a navegação e o comércio da Europa com as Américas e a África Ocidental a partir dos Países Baixos.

\section{O projeto de uma companhia para as Américas e a África Ocidental}

A Companhia das Índias Ocidentais não foi concebida apenas como uma sociedade anônima, com o capital social dividido em ações e sujeita completamente às leis do mercado. Para que ela fosse criada, foi necessário que tanto a Holanda quanto a Zelândia, as principais regiões dos Países Baixos, concluíssem que a fragmentação do monopólio ibérico da navegação e do comércio da Europa com as Américas e a África Ocidental entre várias companhias holandesas não tinha futuro. A livre concorrência ameaçava levar todas as companhias à ruína. À semelhança da Companhia das Índias Orientais, que tinha como objeto o comércio asiático, para promover a hegemonia holandesa no Hemisfério Ocidental era necessário fundar uma companhia estabelecida mediante concessão dos Estados Gerais, com o monopólio na exploração da navegação e do comércio com as Américas e a África Ocidental. Para que a hegemonia holandesa se firmasse no Hemisfério Ocidental, era necessário que a hegemonia ibérica fosse superada. A Companhia das Índias Ocidentais nasce com um objetivo claro. Invadir as colonias portuguesas e espanholas, ocupá-las militarmente e explorá-las comercialmente. ${ }^{15}$ Desde o momento em que a Companhia das Índias Ocidentais foi fundada, ela foi encarada pelos Países Baixos como uma arma contra Portugal e Espanha. As colônias portuguesas e espanholas deviam ser substituídas por colônias holandesas. Quanto mais a hegemonia ibérica fosse minada, mais cresceria a hegemonia holandesa nas Américas e na África Ocidental.

A idéia de fundar uma companhia com o monopólio na exploração da navegação e do comércio com as Américas e a África Ocidental não era nova. Um dos

14 Os Novos Países Baixos, Nieuw-Nederland, foram um território colonizado pelos holandeses na costa nordeste dos Estados Unidos entre as latitudes $38^{\circ}$ e $45^{\circ}$ Norte. Nesta região, os holandeses fundaram Nieuw Amsterdam, Nova Amsterdã, que mais tarde se chamaria Nova York com a ocupação inglesa.

is ISRAEL, Jonathan I. The Dutch Republic. Its Rise, Greatness, and Fall. 1477-1806. Oxford University Press: 1998. p. 325-326. 
primeiros que propôs o que mais tarde se transformaria na Companhia das Índias Ocidentais foi Willem Usselincx, um comerciante, investidor e diplomata nascido em Antuérpia que se estabeleceu em Midelburgo, em 1591. Como comerciante, ele havia viajado à Península Ibérica, tendo a oportunidade de comprovar na prática a riqueza proveniente das colônias portuguesas e espanholas situadas nas Américas e na África Ocidental. Ele chegou a defender que a Companhia das Índias Ocidentais deveria promover a criação de colônias de povoamento, e não de exploração. O meio mais eficaz para promover a navegação e o comércio dos Países Baixos com as Américas e a África Ocidental seria mediante o estabelecimento de colônias povoadas por cidadãos de origem holandesa. Milhares de holandeses deveriam migrar para as Américas, para a Nova Holanda e para os Novos Países Baixos. As colônias de povoamento produziriam matérias-primas que seriam consumidas na metrópole, os Países Baixos. Nos Países Baixos, na metrópole, seriam produzidas manufaturas que seriam consumidas nas colônias de povoamento. Regiões ainda não controladas pelos ibéricos, como as Guianas e os atuais Argentina e Chile, também deveriam receber cidadãos de origem holandesa para assegurar o controle político, militar e comercial dos Países Baixos na América do Sul.

Ainda no começo do século XVII, Usselincx formulou seu projeto, defendendo que a Companhia das Índias Ocidentais deveria ter como objetivo principal o estabelecimento de colônias de povoamento, enviando-o em seguida aos Estados Gerais. Seu projeto não foi bem recebido. Os Estados Gerais não demonstraram nenhum entusiasmo por ele. Eles aguardavam os resultados de uma iniciativa mais concreta. Paulus van Caerden havia sido enviado ao Brasil para fundar o primeiro forte dos Países Baixos no Novo Mundo. Recebido no Brasil com um violento canhoneio de artilharia, este objetivo não foi alcançado, mas ele conseguiu trazer do Brasil açúcar, ouro e prata, atiçando a cobiça holandesa. Os Estados Gerais não estavam interessados no projeto de Usselincx, no estabelecimento de colônias de povoamento. O importante era conquistar, ocupar e explorar colônias portuguesas e espanholas. Com o monopólio na exploração da navegação e do comércio nas Américas, da Terra Nova até o Estreito de Magalhães, e na África Ocidental, dotada de autoridade judicial e militar à luz do previsto no privilégio que lhe foi concedido pelos Estados Gerais, a Companhia das Índias Ocidentais tinha como missão erguer o imperium holandês à custa dos portugueses e dos espanhóis. ${ }^{16} \mathrm{O}$ projeto de Usselincx não foi acolhido pelos Estados Gerais. Seu maior temor, o de que se fundaria uma companhia que não teria nenhum outro interesse a não ser o lucro, confirmou-se. ${ }^{17}$

${ }_{16}$ HEIJER, Henk den. op. cit., p. 25: "Vanzelsprekend zou darbij ook de Spaans-Portugese macht worden aangetast"

17 Id. Ibid., p. 28: "Zijn vrees dat de niewue compagnie in handen zou komen van kooplieden die slechts 'de winste tot noortsterre ende de begeerlickheyt voor compas hebben' uitte hij nog eenmaal in een pamflet, dat in 1620 door de Staten-Generaal ter zijde werd gechoven" 
Mais tarde, desiludido com os Países Baixos, ele se deslocou para a Suécia, levando consigo seu projeto de estabelecer companhias de comércio que fomentassem o surgimento de colônias de povoamento. Mais uma vez, ele fracassou.

Em 9 de abril de 1609, os Países Baixos e a Espanha haviam assinado, em Antuérpia, a Trégua de Doze Anos. O estadista Johan van Oldenbarnevelt, que havia desempenhado um papel importante no processo de independência dos Países Baixos contra a Espanha, após a celebração desta trégua, entendeu, ao contrário de Usselinx, que a fundação da Companhia das Índias Ocidentais ameaçava a paz com os espanhóis. No Acordo da Trégua, estava previsto que os holandeses não podiam se estabelecer em regiões que estavam sob o controle português ou espanhol. Oldenbarnevelt, que se transformou num dos principais obstáculos à fundação da Companhia das Índias Ocidentais, teve um fim trágico. Num processo que até hoje não é lembrado como um modelo de lisura e de imparcialidade, ele foi condenado pelo crime de alta traição e decapitado em 1619. Com sua execução, abriu-se caminho para a fundação da Companhia das Índias Ocidentais. A Trégua dos Doze Anos com a Espanha encerrou-se em 1621, seguindo-se uma proibição à navegação e ao comércio dos territórios controlados por Portugal e Espanha com os Países Baixos. Em 1621, no mesmo ano em que esta Trégua se findou, os Estados Gerais fundaram a Companhia das Índias Ocidentais com a concessão do privilégio.

Passaram-se três desde a fundação da Companhia das Índias Ocidentais para reunir o capital inicial necessário ao seu funcionamento. Na concessão do privilégio, previu-se que a Companhia das Índias Ocidentais deteria originalmente o monopólio durante vinte e quatro anos na exploração da navegação e do comércio com as Américas e a África Ocidental. Da mesma maneira que a Companhia das Índias Orientais, a Companhia das Índias Ocidentais, à luz do privilégio que lhe foi concedido, tinha o direito, como longa manus dos Estados Gerais, de exercer prerrogativas que são completamente desconhecidas pelas sociedades anônimas, sujeitos jurídicos de direito privado. A Companhia das Índias Ocidentais estava autorizada, sob supervisão dos Estados Gerais, a manter guarnições militares, a dispor de navios de guerra, a indicar governadores, a celebrar alianças com povos nativos. Seu objetivo maior, exercer o monopólio na exploração e na navegação do comércio com as Américas e a África Ocidental, só poderia ser alcançado com a invasão, a ocupação militar e a exploração comercial das colônias portuguesas e espanholas. A Companhia das Índias Ocidentais não tinha apenas objetivos comerciais. Ela era uma máquina de guerra a serviço dos Países Baixos. Os Estados Gerais podiam encarregar-se, quando fosse necessário, do fornecimento de armas, munições, navios de guerra e tropas militares para que a Companhia das Índias Ocidentais cumprisse sua finalidade, substituir a hegemonia ibérica pela hegemonia holandesa nas Américas e na África Ocidental. Aos comandantes e governadores a serviço da Companhia das Índias Ocidentais, era exigido que eles prestassem um juramento de dupla fidelidade, à Companhia e aos Estados Gerais. 
Eles não prestavam contas apenas à Companhia das Índias Ocidentais, mas ao Governo Central dos Países Baixos.

\section{A Companhia das Índias Ocidentais}

A Companhia das Índias Ocidentais não nasceu motu proprio com a livre subscrição de seu capital social, como ocorre com as sociedades anônimas pela integralização de suas ações. Para que a Companhia surgisse em 3 de junho de $1621,{ }^{18}$ foi necessário que os Estados Gerais, o Governo Central dos Países Baixos, interviesse com a expedição de uma carta-patente que lhe outorgou o privilégio durante vinte e quatro anos na exploração da navegação e do comércio com as Américas e a África Ocidental. ${ }^{19}$ A Companhia das Índias Ocidentais deve suas origens a um ato de Estado que lhe conferiu o controle da navegação e do comércio com as Américas e a África Ocidental, com características de monopólio. ${ }^{20}$ A Carta-Patente da Companhia tinha quarenta e cinco artigos, com um conteúdo semelhante ao da Companhia das Índias Orientais, de 1602. O objetivo era claro. Da mesma maneira que na Ásia, onde os holandeses haviam conquistado uma posição política, militar e comercial crescentemente hegemônica à custa dos portugueses, nas Américas e na África Ocidental a hegemonia holandesa precisava ser construída à custa dos portugueses e dos espanhóis.

A estrutura administrativa da Companhia das Índias Ocidentais estava prevista no art. 11 da Carta-Patente. A controvérsia a respeito de que regiões e cidades dos Países Baixos deveriam participar da companhia surgira desde 1618. Para a Holanda, a principal região dos Países Baixos, a Companhia das Índias Ocidentais deveria ter uma estrutura descentralizada, composta de quatro câmaras. A política geral a ser seguida pela Companhia como um todo seria determinada pelo Conselho Federal de Administração, os Heren XIX, os Senhores XIX. O direito de voto de cada câmara no Conselho Federal de Administração seria fixado em função do capital subscrito em cada uma delas. A Holanda estava em condições de investir mais na Companhia das Índias Ocidentais do que as outras regiões dos Países Baixos. Sendo assim, ela desejava ter mais voz no Conselho Federal de Administração, determinando suas decisões. Amsterdã, capital econômica da região da Holanda e dos Países Baixos como um todo, teria uma participação na companhia de 50\%; a Zelândia, principal rival comercial da Holanda, com Midelburgo como capital, ficaria

18 HEIJER, Henk den. op. cit., p. 30: "Op 3 juni 1621 stemden de Staten-Generaal in met het voorliggend concept-octrooi en was de oprichting van de WIC een feit".

19 Após a expiração dos vinte e quatro anos iniciais, os Estados Gerais precisavam manifestar-se a respeito da necessidade de prorrogação do prazo de existência da Companhia das Índias Ocidentais.

20 A Companhia detinha o monopólio da navegação e do comércio não apenas nas Américas e na África Ocidental, do sul do Trópico de Câncer até o Cabo da Boa Esperança, mas também sobre ilhas do Oceano Atlântico. 
com 25\%; e um grupo de cidades da Holanda e da Frísia Ocidental, uma região periférica dos Países Baixos, contaria cada um com uma participação de $12,50 \% .{ }^{21}$ A intenção da Holanda era clara. Controlar com a maioria absoluta dos direitos de voto no Conselho Federal de Administração o processo de tomada de decisões que estabeleceria os rumos da Companhia das Índias Ocidentais. Poderia até haver uma quinta câmara, desde que a Frísia Ocidental e Groninga juntas contribuíssem com meio milhão de florins em prol da fundação da Companhia das Índias Ocidentais. A Holanda não conseguiu tudo o que queria, mas suas principais sugestões foram acatadas. De acordo com sua proposta, a Companhia foi dotada de uma estrutura descentralizada, federalizada. Foram adotadas cinco câmaras regionais, pertencentes a Amsterdã, Zelândia, Roterdã, Groninga e Região Norte. ${ }^{22} / 23$ À semelhança da Companhia das Índias Orientais, o capital e as contas de cada uma destas câmaras eram administrados separadamente.

Não se permitiu que Amsterdã assumisse o controle político inconteste da Companhia das Índias Ocidentais. A participação das câmaras na Companhia não era determinada apenas pelo montante de capital investido, mas também pela repartição tributária. ${ }^{24}$ Sendo assim, a participação de Amsterdã na Companhia foi arbitrada em quatro nonos, Zelândia dois nonos e as outras três câmaras menores com cada uma um nono. ${ }^{25}$ Conjuntamente, estas participações formavam a chamada "negensleutel", a chave dos nove, expressão maior da relação de poder na Companhia. Por mais que se quisesse conter o poder da Holanda, esta relação de poder favorecia as cidades e as regiões mais ricas dos Países Baixos. Os administradores das câmaras eram escolhidos dentre os principais acionistas. Para ser considerado acionista principal da Câmara de Amsterdã, era necessário possuir ao menos seis mil florins em ações da Companhia das Índias Ocidentais. Para as outras câmaras, bastavam quatro mil florins. No Conselho Federal de Administração, os Senhores XIX, Amsterdã tinha oito representantes; Zelândia, quatro; as três pequenas câmaras dois cada; e os Estados Gerais, um. ${ }^{26} \mathrm{O}$ Conselho Federal de

${ }^{21}$ HEIJER, Henk den. op. cit., p. 29-30: "In 1618 ontstond een controverse over de vraag welke gewesten en steden in de compagnie zouden participeren. De Staten van Holland hadden daarover een uitgesproken mening en wensten een gedecentraliseerde organsatie bestaande uit vier kamers. Amsterdam zou een belang van $50 \%$, Zeeland $25 \%$ en een groep Hollandse en Westfriese steden elk 12,50\% moet verwerven”

22 A Região Norte, o Noorderkwartier, é uma região histórica dos Paises Baixos que corresponde à parte setentrional da Holanda.

23 HEIJER, Henk den. op. cit., p. 31: "Geheel in overeenstemming met de wensen van de Staten van Holland werd het bestuur verdeeld over vijf kamers: Amsterdam met twintig, Zeeland met twaalf en Maze, Noorderkwartier en Stad en Land elk met veertien bewindhebbers".

24 Id. Ibid., p. 31: "Het aandeel van de kamers in de WIC werd niet alleen door het ingebrachte kapitaal bepaald, maar tevens door het in de Republiek geldende belasting- of repartitiestelsel".

25 Id. Ibid., p. 31: "Zo verwierf Amsterdm vier negende, Zeeland twee negende en de drie kleine kamers elk een negende deel in de Compagnie"

26 Id. Ibid., p. 31: "Het hoogste bestuurcolege van de WIC werd door de Heren Negentien gevormd, waarvoor Amsterdam acht, Zeeland vier, de drie kleine kamers elk twee en de Staten-Generaal een vertegenwoordiger 
Administração reunia-se de duas a três vezes por ano. Durante estas sessões, decidiamse questões vitais para a Companhia das Índias Ocidentais, como a adoção de diretrizes políticas, a preparação de expedições marítimas, a distribuição de dividendos. O Conselho também era responsável pela prestação de contas da Companhia aos acionistas, elaborada a partir dos registros contábeis fornecidos pelas cinco câmaras. A presidência do Conselho Federal de Administração cabia à Câmara de Amsterdã por seis anos e à Câmara da Zelândia por dois anos. ${ }^{27}$ Nas cinco câmaras, os administradores eram responsáveis pela execução das diretrizes políticas adotadas pelo Conselho Federal de Administração, tomandose cuidado para que houvesse uma coordenação das atividades. Cada câmara tinha seu próprio sistema de administração e contabilidade, sendo transmitidas regularmente às outras câmaras prestações de contas. ${ }^{28}$ Dependendo do tamanho de cada câmara, havia comissões encabeçadas por administradores encarregadas de assuntos específicos, como a gestão dos estaleiros da companhia, a compra de mercadorias a serem exportadas e a venda de produtos importados. ${ }^{29}$ Os administradores eram remunerados por seus serviços com uma comissão de $1 \%$ incidente sobre o valor das mercadorias a serem exportadas e da venda de produtos importados, assim como sobre o lucro com a venda de bens e navios arrestados. ${ }^{30}$

A Companhia das Índias Ocidentais tornou-se uma das principais armas dos Países Baixos contra Portugal e Espanha. Empenhada em promover com exclusividade a navegação e o comércio dos Países Baixos com as Américas e a África Ocidental, a Companhia esforçou-se ao máximo para minar o monopólio ibérico. Ela não foi criada diretamente pela iniciativa privada, mas pelo Governo Central dos Países Baixos, pelos Estados Gerais, para lutar contra o inimigo. Nem sempre os interesses da iniciativa privada holandesa estavam de acordo com os interesses dos Estados Gerais, os quais deviam prevalecer para assegurar a sobrevivência e a prosperidade dos Países Baixos. Da mesma forma que a Companhia das Índias Orientais na Ásia, a Companhia das Índias Ocidentais era um instrumento dos Estados Gerais para estimular a navegação, a guerra e o comércio dos Países Baixos nas Américas e na África Ocidental em detrimento dos interesses dos

leverden"

27 Id. Ibid., p. 31: "Het voorzitterschap van het college was voor zes jaar in handen van de kamer Amsterdam en voor twee jaar in handen van de kamer Zeeland"

28 HEIJER, Henk den. op. cit., p. 31: "De kamers hielden hun eigen administratie en boekhouding bij, en zonden rekeningen van scheepsuitredingen en overzichten van veilingen van retourwaren binnen drie maanden naar de andere kamers"

29 Id. Ibid., p. 31: "Al naar gelang de grootte van een kamer was een bewindhebber lid van een of meerdere commissies die met bepaalde taken waren belast. Zo waren er commissies voor het beheer van de compagniewerven, de equipage en victualiëring van schepen, de inkoop van handelsgoederen en de verkoop van retourwaren"

$30 \quad$ Id. Ibid., p. 31: "Voor hun diensten ontvingen de bewindhebbers 1\% provisie van uitgaangde en inkomende goederen alsmede van in beslag genomen goederen en schepen" 
portugueses e dos espanhóis. Para tanto, como longa manus dos Estados Gerais, do governo central dos Países Baixos, ela foi dotada do direito de celebrar alianças, de dizer o direito, de fundar colônias e de manter efetivos militares. Mas a situação nas Américas e na África Ocidental não era a mesma da existente na Ásia. Desde o começo do século XVI, Portugal e Espanha haviam estabelecido colônias nas Américas e feitorias na África Ocidental. Para que a Companhia das Índias Ocidentais cumprisse seu objetivo de promover a navegação e o comércio das Américas e da África Ocidental com os Países Baixos, substituindo a hegemonia ibérica na região do Atlântico pela hegemonia holandesa, era necessário entrar em guerra contra os ibéricos. Em caso de necessidade, os Estados Gerais podiam colocar à disposição da Companhia das Índias Ocidentais efetivos militares, mas não era apenas o interesse político e militar dos Estados Gerais que devia prevalecer. Os investidores não haviam aplicado suas economias nas ações da Companhia para que ela participasse de guerras que não tivessem como objeto a conquista de territórios lucrativos. Um dos maiores obstáculos para a subscrição do capital necessário para que a Companhia das Índias Ocidentais começasse a funcionar regularmente foi justamente este conflito entre a razão de Estado e a busca do lucro. Muitos investidores ficavam reticentes diante dos conflitos que podiam surgir não apenas com os Estados Gerais, mas entre os acionistas e os administradores das câmaras. A subscrição do capital da Companhia foi lenta, tendo sido necessário fazer muita propaganda tanto interna quanto externamente para concluir este processo. Apenas em meados de 1623 a Companhia das Índias Ocidentais passou a dispor de capital suficiente para iniciar suas atividades. Dentro de cinco meses após terem manifestado seu interesse em comprar ações, os investidores estavam obrigados a fornecer um terço do capital prometido. O restante devia ser disponibilizado dentro de três anos. ${ }^{31} \mathrm{O}$ capital social da Companhia entre 1623 e 1629 foi aumentado quatro vezes até a importância de 17.090.000 florins, permanecendo inalterado desde então até sua falência em $1674 .^{32}$

Conclusões

A Companhia das Índias Ocidentais nasceu com as bênçãos do Estado, unificando companhias pré-existentes que tinham como objeto a exploração da navegação e do comércio com as Américas e a África Ocidental. Seus objetivos eram claros. Entrar em guerra se fosse necessário com Portugal e Espanha, atacar e capturar navios mercantes

31 HEIJER, Henk den. op. cit., p. 33: "De aandeelhouders waren verplicht om binnen vijf maanden na inschrijving een derde van het toegezegde kapitaal te fourneren. Het resterende bedrag moest binnen drie jaar op tafel worden gelegd".

32 Id. Ibid., p. 33: "Wegens chronisch geldgebrek zou het aandelenkapitaal van de WIC tussen 1623 em 1629 nog viermaal worden verhoogd tot een bedrag van 17.090.000 gulden. Daarna zou het aandelenkapitaal zich tot aan het faillessement in 1674 niet meer wijzingen" 
ibéricos e conquistar as colônias de Portugal e Espanha. Foi necessária a execução de Oldenbarneveldt para que os defensores da guerra com os ibéricos se consolidassem no poder, criando em seguida uma companhia que tinha como metas principais a navegação, a guerra e o comércio.

Um empreendimento híbrido, a Companhia das Índias Ocidentais agia tendo em vista os interesses dos Estados Gerais, do Governo Central, e dos acionistas, da iniciativa privada. Sendo assim, o Conselho Federal de Administração era sempre em última instância responsável perante os Estados Gerais dos Países Baixos. As autoridades da Companhia das Índias Ocidentais tinham o dever de prestar-lhe juramento de lealdade. A Companhia não pode ser considerada pura e simplesmente, juntamente com a Companhia das Índias Orientais, uma antecessora das sociedades anônimas. Embora ela tivesse características de direito privado, como as sociedades anônimas contemporâneas, ela exercia competências de direito público de importância fundamental. Quando a Companhia das Índias Ocidentais conquistou territórios nas Américas e na África Ocidental, estes territórios nunca deixaram de pertencer em última instância ao Estado. ${ }^{33}$

A importância histórica da Companhia das Índias Ocidentais não reside no fato de ela ter sido ou não uma antecessora das sociedades anônimas, mas, pelo contrário, em ela ter corporificado uma relação simbiótica entre o Governo e a iniciativa privada. A Companhia representa o início de uma relação íntima e duradoura entre o público e o privado, ${ }^{34}$ presente constantemente no capitalismo. O principal instrumento do expansionismo holandês nas Américas e na África Ocidental, a Companhia das Índias Ocidentais, à semelhança da Companhia das Índias Orientais, é a precursora das empresas transnacionais, tendo sido dotada de prerrogativas públicas, como a de entrar em guerra, prender e executar condenados, negociar tratados, cunhar moedas e estabelecer colônias, sempre sob a supervisão e com o beneplácito dos Estados Gerais.

São Paulo, fevereiro de 2010.

\section{Referências}

BELIËN, H. M.; DEURSEN, A.Th. van; SETTEN, G.J. van. Gestalten van de Gouden Eeuw. Een Hollands groepsportret. Amsterdam: Bert Bakker, 2005.

33 HEIJER, Henk den. De geoctrooieerde compagnie. De VOC en de WIC als voorlopers van de naamloze vennotschap. Deventer: Kluwer, 2005, p. 68: "Toen de VOC en de WIC in de loop van de zeventiende en achttiende eeuw daadwerkelijk gebieden overzee verwierven, werden zij steeds meer een verlengstuk van de staat".

${ }^{34}$ Id. Ibid., p. 68: "De bemoeienis van de Staten-Generaal met de oprichting van de VOC en de WIC was het begin van een langdurige symbiotische relatie tussen de overheid en private handelsonderneming" 
BLOM, J.C.H.; LAMBERTS, E. Geschiedenis van de Nederlanden. 3. ed. Baarn: Hbuitgevers, 2008.

BRAKEL, S. van. De Hollansche Handelscompagnieën der zeventiende eeuw. Hun Onststaan, hunne Inrichting. Haia: Martinus Nijhoff, 1908.

COOK, Harold J. Matters of Exchange. Commerce, Medicine, and Science in the Dutch Golden Age. Yale:Yale University Press, 2007.

HEIJER, Henk den. De geoctrooieerde compagnie. De VOC en de WIC als voorlopers van de naamloze vennotschap. Deventer: Kluwer, 2005.

HEIJER, Henk den. De geschiedenis van de WIC. Walburg Pers: Zutphen, 2002.

ISRAEL, Jonathan I. The Dutch Republic. Its Rise, Greatness, and Fall 1477-1806. Oxford University Press: 1998.

ISRAEL, Jonathan I. The Dutch Republic and the Hispanic World 1606-1661. Oxford University Press: 1986.

SCHULTEN, C.M. Nederlandse expansie in Latijns Amerika. Brazilië: 1624-1654. Bussum: Fibula/ Van Dishoeck N.V., 1968. 